\title{
Sexual Health Education At Home And At School
}

\section{Nergiz ERYILMAZ1 ${ }^{\text {(iD Barş KÖSRETAŞ2 }}$ (iD Safa Abdulsamet ATAMAN ${ }^{3}$ iD}

${ }^{1}$ Karamanoglu Mehmetbey University, Vocational School of Health Services, Department of Medical Services and Techniques, Karaman, Turkey, nergizeryilmaz@kmu.edu.tr (Sorumlu Yazar/Corresponding Author)

${ }^{2}$ Karamanoglu Mehmetbey University, Vocational School of Health Services, Department of Medical Services and Techniques, Karaman, Turkey, bariskosretas@kmu.edu.tr

${ }^{3}$ Karamanoglu Mehmetbey University, Vocational School of Health Services, Department of Therapy and Rehabilitation Karaman, Turkey, safaataman@kmu.edu.tr

\begin{tabular}{ll}
\hline Article Info & ABSTRACT \\
\hline Article History & $\begin{array}{l}\text { World Health Organization (WHO) defines sexual health not only as of the absence of functional disorder } \\
\text { or disability, but also as a state of complete sexual well-being in a physical, emotional, mental, and social }\end{array}$ \\
Received: 26.02.2021 & $\begin{array}{l}\text { sense. Interruption of sexual health, which is one of the most important elements of general health, can } \\
\text { Accepted: 06.05.2021 }\end{array}$ \\
Published: 25.08.2021 & $\begin{array}{l}\text { cause physical and mental distress. Adolescence is the most risky period when false beliefs, attitudes and } \\
\text { behaviors about sexual health and reproductive health can be developed, such as the spread of STDs due } \\
\text { to increased sexual desire, unsafe sexual behaviors and unwanted pregnancies. Since sexual health }\end{array}$ \\
Keywords: & $\begin{array}{l}\text { education may be different for each country and culture, it may be appropriate to start education with } \\
\text { families by educating parents in the most appropriate way and including relevant subjects in school }\end{array}$ \\
Sexual Health Education, & programs with professional educators. The current study aims to emphasize the importance of sexual \\
Families, & health education for adolescents both in the family and educational institutions. \\
Adolescents. &
\end{tabular}

\section{Evde ve Okulda Cinsel Sağlık Ĕgitimi}

\begin{tabular}{|c|c|}
\hline Makale Bilgileri & ÖZ \\
\hline Makale Geçmişi & Cinsel sağlık; Dünya Sağlık Örgütü'nün ifadesiyle; sadece hastalık, işlev bozukluğu veya sakatlı̆̆ın olmaması değil, \\
\hline Geliş: 26.02.2021 & $\begin{array}{l}\text { sellikle ilişkili olarak fiziksel, duygusal, zihinsel ve sc } \\
\text { elerinden biri olan cinsel sağlığın sekteye uğraması ki }\end{array}$ \\
\hline Kabul: 06.05.2021 & bilir. Özellikle cinsel istek ve arzunun arttığı ve güvenli olmayan cinsel davranışlara bağlı CYBH' in yayıllımı ve \\
\hline Yayın: 25.08.2021 & $\begin{array}{l}\text { adölesan gebelikler gibi cinsel sağlık ve üreme sağlı̆̆ konusunda yanlış inanış tutum ve davranışların } \\
\text { geliștirilebileceği en riskli dönem olan ergenlik döneminde cinsel sağlık eğitiminin yeterli bilgi ve donanıma sahip }\end{array}$ \\
\hline Anahtar Kelimeler: & $\begin{array}{l}\text { kişiler tarafından verilmesi gençlerde gelişebilecek sorunları azalmasında ve/veya önlenmesinde büyük rol } \\
\text { oynavabilir. Cinsel sağlık eğitimi her ülke ve her kültür için farklı olabileceğinden, adölesanlara cinsel sağlık }\end{array}$ \\
\hline Cinsel Sağlik Eğitimi, & jitiminin verilmesi söz konusu olduğunda, ebeveynler, okul hemşireleri, öğretmenler ve profesyonel eğitimciler \\
\hline Aileler, & kli bilgilendirmeleri yaparak farkındalık yarata \\
\hline Adölesanlar. & $\begin{array}{l}\text { Bu çalışmanın amacı, hem ailede hem de eğitim kurumlarında ergenler için cinsel sağlık eğitiminin önemini } \\
\text { vurgulamaktır. }\end{array}$ \\
\hline
\end{tabular}

Atıf/Citation: Eryılmaz, N., Kosretas, B., \& Ataman, S.A. (2021). Sexual health education at home and at school. Genel Săglık Bilimleri Dergisi, 3(2), 152-159.

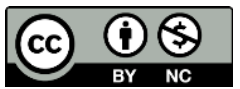

"This article is licensed under a Creative Commons Attribution-NonCommercial 4.0 International License (CC BY-NC 4.0) 


\section{INTRODUCTION}

Sexuality starts in the mother's womb and continues until the end of life which includes an individual communicate with somebody, the way individual expresses himself/herself in life, and sometimes the effort to understand the other person (Society for Sexual Education Treatment and Research [CETAD], 2006). Interruption of sexual health, which is one of the most important elements of general health, can cause physical and mental distress. Problems related to sexual health also threaten the general health of the person and make people unhappy both in their social and private lives (Bozdemir \& Özcan, 2011). Adolescence is the most risky period when false beliefs, attitudes and behaviors about sexual health and reproductive health can be developed, such as the spread of sexually transmitted diseases (STDs) due to increased sexual desire, unsafe sexual behaviors and unwanted pregnancies (International Children's Center, n.d.). In Turkey, Ministry of Health Department (2005) introduced to National Strategic Action Plan (NSAP) which states that adolescents do not have sufficient knowledge about healthy sexuality and contraception methods. Findings of NSAP indicates that parents a do not have sufficient knowledge about sexual health education too. Adolescents need adequate and correct sexuality and sexual health education to manage the adolescence period well, to improve the sexuality and sexual health of adolescents, to protect and maintain this healthy process, and to ensure that adolescents are least affected by the risks that threaten their sexual health (Zeren \& Gürsoy, 2018). The current study aims to emphasize the importance and necessity of sexual health education for adolescents both in the family and in educational institutions.

\section{Sexuality and Sexual Health}

Sexuality is not only the gathering of bodies, but also the state of health in which people are together in spiritual, emotional, and intellectual terms (WHO, 2010). Sexuality is an essential requirement that can be learned over time as well as instinctively. Moreover, sexuality may be affected by many factors such as economic, religion, biological, society, culture and social. (Bozdemir \& Özcan, 2011; Esencan \& Beji, 2015; WHO, 2010).

The definition of sexual health was firstly introduced in 1975 by the World Health Organization (WHO) which states that "the integration of the somatic, emotional, intellectual and social aspects of sexual being, in ways that are positively enriching and that enhance personality, communication, and love". In the developed world, the most recent definition of sexual health is developed by WHO in 2006:

"Sexual health is a state of physical, emotional, mental and social well-being in relation to sexuality; it is not merely the absence of disease, dysfunction or infirmity. Sexual health requires a positive and respectful approach to sexuality and sexual relationships, as well as the possibility of having pleasurable and safe sexual experiences, free of coercion, discrimination, and violence. For sexual health to be attained and maintained, the sexual rights of all persons must be respected, protected and fulfilled'.

The current study aims to emphasize the importance of sexual health education for adolescents both in the family and educational institutions.

\section{The Importance of Sexual Health Education}

According to the Ministry of Education regulations in Turkey, the curriculum does not include an official sexual health education course. This subject is generally addressed in science or biology courses, but not under the name of "Sexual Health Education". Çuhadaroglu (2017) stated that Turkey had never a national curriculum on sexual health and concluded that the subject of sexual health is not included in the curriculum at the national level in Turkey. Also, Çuhadaroğlu (2017) highlighted that the youth may receive sexual education in university curricula at a very limited scope that is usually effective. 
There are different opinions and studies on how, where, and at what age sexual health education should be provided. Home-based, school-based, and hospital-based training comes to mind when it comes to sexual education to be provided to individuals or groups in general. The necessity of schoolbased sexual education programs on how to provide sexual education, which is crucial in terms of preventing unwanted pregnancies and STDs cannot be overstated; however, unfortunately, young people cannot always access sexual education programs that address these issues openly (Grose et. al., 2014). School can sometimes be the place where the information learned in the family is reinforced, and it can sometimes be the initial source of information. According to the results of a study by Robinson et al. (2017) on receiving information from parents with regards to the importance of sexual health education at primary schools, the majority of the participants (79\%) said sexual health education should be provided to children at primary school age so that children use the information during adolescence and thus prevent the spread of misinformation regarding sexuality and start using the information they receive correctly. In this regard, Haruna et al. (2018) stated that game-based learning and gamification are effective tools in improving sexual health knowledge among middle school adolescents (ages 1115) in Tanzania.

Although short focus groups on sexual education have been used frequently since the 1960s (Barratt, 2008), some studies show that sexual education through peer education organized based on culture and gender may accomplish sexual education goals (Stephenson et al., 2004; Wong et al., 2019). In the USA, Sprecher et al. (2008) collected sexual education data from more than 6,000 university students in a study conducted between 1990 and 2006. The participants cited their peers, the media, and their parents (mothers in particular) as the source of their sexual education. Also, the participants stated that they talked about sexual issues with their peers more than they did with their parents. Although the rank of students' sexual health education resources has not changed throughout the years, the ratio of students' sexual health education resources has increased. The researchers pointed out that the increasing proportion of the media was quite natural due to the proliferation of the internet and sexually explicit television programs. Also, Sprecher et al. (2008) highlighted that although young adults' role of "peers" in sexual education increased over time from 1990 to 2006, they communicated more often with professionals about "sex". Another study conducted by Narushima et al. (2020) on young people aged 16-24 showed that peers were listed as the primary source of information with regards to sexuality, followed by sex education received at school and on media. So, supported by the previous studies, it can be assumed that reinforcing sexual education with peer teaching may be logical.

Education on sexually transmitted diseases, family planning, and healthy living may occasionally include sex education content. Sex education can be interpreted differently in each country and culture. Various studies conducted in different countries and cultures have concluded that sex education should be included in school and university curricula (Bouclaous et al., 2021; Çuhadaroglu, 2019; Lin \& Lin, 2018 ); however, studies on improving the quality of this education is limited (Seiler-Ramadas et al., 2021). A study conducted by Sommart \& Sota (2013) on high school students to assess the effectiveness of a school-based sexual health education program in Khon Kaenin, Thailand showed that this program can improve the students' sexual health knowledge and sexuality. Families of high school girls in Kenya stated that they rarely talk about sexual health, mostly issues such as virginity and pregnancy were discussed in families, and STDs were ignored during a conversation among their children due to mothers' inadequate information on STDs (Wanje et al., 2017). Providing sex education to high school students not only can inform them about sexually transmitted infections but also helps them improve their knowledge of sexual health and help them to reduce their risky sexual behaviors.

The importance of family-based sexuality education cannot be denied; however, research has shown that many parents are too embarrassed to discuss the issue of sexuality or do not know how to talk to their children about this issue (UNFPA, 2018). Some studies also showed that some parents are 
against sexual health education and do not talk about sexual issues with their children (Ashraah et al., 2013; Nadeem et al., 2021). In a study, Buston et al. (2002) explored students' views on school-based sex education. Detailed interviews with the students revealed that the students were unwilling to participate in an education that did not contribute to their sexual well-being, they were also uncomfortable during sexual education lessons and were not willing to actively participate in the lessons. Researchers have shown that the role and behaviors of the teacher providing sexual education are important in terms of preventing these situations and creating a sense of trust among students, and if sex education provides in a fun way it can be more beneficial for students (Buston et al., 2002). In a study on attitudes and experiences of high school students living in New Brunswick, Canada at school and home, Byers et al. (2003) stated that students thought that the sexual health education curriculum did not meet their needs, the curriculum did not include interesting subjects, and the information was about adolescence. A parallel study assessing the deficiencies in sex education content was conducted by Astle et al. in 2021. In this study, researchers examined the views of 38 students in a USA university on sex education they received. The youth reported that their sex education was insufficient and had out-ofdate information. Participants of the study stated that their sex education involved intense scaring strategies, it did not help them, and they found this education to be weird. At the end of the study, the results revealed that sexual education generally did not meet the needs of young people. They recommended that this sexual education should be provided earlier, more frequently, and in a contemporary manner with realistic and updated information (Astle et al.,2021). A study conducted by Leung et al. (2019) also examined the sex education policies of English speaking in the USA and UK and Chinese speaking in Hong Kong, China, and Taiwan and found various gaps and insufficiency in the sex education provided in these countries. They suggested that sex education policies and programs should be improved by science-based theories involving contemporary adolescence development theories and ecological models. They showed that sex education should involve more effort and action and the educators (e.g. teachers and social workers) and parents are in desperate need of new skills to increase the effectiveness of sex education programs (Leung et al., 2019).

Another study conducted in Iran explored mothers' views on sexual health education towards their adolescent daughters, their needs, and the obstacles they encounter when talking to their daughters (Shams et al., 2017). They (2017) found that there is a disagreement about sexual health education for adolescent girls. For example, some mothers stated that their daughters may act rudely if they received education on this subject and the education should only involve adolescence and menstruation if it is needed, while others stated that their daughters should know everything about it. Besides, religious belief and embarrassment were the main obstacles for women and mothers to think that their daughters may engage in risky sexual behavior. Parents whose children take sexual health education were concerned that their children's interest in sexuality may increase. Therefore, parents stated that their children don't need to receive knowledge about sexuality, fearing that it might mislead the children. However, in a study conducted on 1,719 adolescents in the USA, it was revealed that adolescents who received sexual health education were in the lower risk group for early onset of sexuality and adolescent pregnancies compared to those who did not (Kohler et al., 2008). It is clear that sexual health education is s much more than knowledge of reproductive system of anatomy and physiology (Çalışandemir et al., 2010). Sexual health education is not only teaches accurate and reliable information about avoiding risky sexual behaviors and safe sexuality, but also provides understanding of sexuality from all sides by addressing the psychosocial, emotional, physical and mental dimensions. In addition, CSE helps individuals to get to know themselves, to make conscious choices by creating awareness about their sexual life, to obtain accurate and reliable information about sexuality (Zeren and Gürsoy,2018).

Regarding the questions that children cannot ask from their families and are ashamed to ask, the use of mobile applications as an educational tool at this age can be a good solution. In this regard, 
Brayboy et al. (2017) developed a smartphone application and evaluated whether the implementation is appealing for 39 girls aged 12-17 in Rhode Island. 22 girls and other girls in the focus group answered questions on sexual health and interview before and after the implementation. They concluded that the application can be used in daily life at any time and has the opportunity to facilitate accessibility to real sexual health information easily and promptly. In a study, Oosterhoff et al. (2017) also examined the data from a program that provided online sex education in 5 countries of China, Egypt, Kenya, Mexico, and India. Similar to other studies, they mentioned the difficulty of obtaining reliable information on sex for the majority of young people, and they listed some elements such as education authorities, governments, and religion as traditional watchdogs of sexual education. They stated that these traditional watchdogs restrict the content of sexual education, access to education, and materials. They listed some factors such as being anonymous, portable, allowing interaction, the capability of being updated to respond to requests as the reasons why online sex education should become widespread. According to these studies, we can conclude that online applications can offer a new perspective in terms of providing sex education in a way that is different from traditional methods.

\section{CONCLUSION and SUGGESTIONS}

Learning about sexuality, which is an indispensable part of life, from wrong sources may make it difficult to teach correct information later or correct the wrong information. Parents must also have sufficient knowledge and equipment to provide accurate and reliable information to the child because they are the first and most accurate source for children. Education, culture, the family in which they grew up in their community, sense of self, their perspective on the sexual identity of the parents or sex educators educating the children, and similar factors may influence the sex education they provide to children and their view on such education. Even if the parents feel inadequate in the face of the questions asked by the children who are positive about sexual communication, conscious parents with high awareness will make an effort to answer these questions correctly. It is clear that sexuality, which is a necessity of being human and is among the basic needs, is learned from the family initially, and afterward, it should be supported and maintained by school education included in the school curriculum. Integrating sexual health education into school curricula based on the unique cultures of each country by considering differences may be beneficial. Also, it has been suggested that sexual education courses should be taught at the university level in conservative countries like Turkey (Çuhadaroglu, 2017). When it comes to teaching sexual health education to society, school nurses should take the lead in raising awareness by informing parents, teachers, and students about the necessity and importance of sexual health education (Maryland \& Gonzalez, 2012 ). Collaboration of school nursing, teachers, and school principals may have a positive effect on sexual health education.

Deprived of accurate and reliable sexual information, prospective parents may get wrong information from their peers or thought through social media and may face voluntary miscarriages in non-hygienic environments, maternal and infant mortality, and injuries. They may experience negative effects of sexuality such as STDs, unwanted pregnancies, miscarriages, abortions, abnormal attitudes towards masturbation, and sexual dysfunctions instead of positive effects of sexuality such as joyful sex life and planned pregnancies.

Finally, considering that parents who do not talk to their children about sexual health have not received a course or education at school. Children need to know their bodies through education involving drama, role play, telling, demonstrating, and feedback techniques as well as using the right resources for learning about healthy sexual behavior by using online applications and new technologies. Otherwise, observed negative attitudes and behaivours are not surprising. To get out of this vicious cycle, the chain must be broken at some point. Based on the principle that you change yourself and the world changes 
with you, if parents are the first sexual educators of children, we can change families by changing an individual and change the society by changing a family.

\section{Funding Sources}

No financial support was received in the study.

\section{Conflict of Interests}

The authors declare that are no conflict of interests.

\section{Author Contributions:}

Design: S.A.A.; Data collection or processing: N.E.; Analysis or interpretation: N.E.; Literature search: N.E., B.K., S.A.A.; Writing: B.K.

\section{REFERENCES}

Ashraah, M. M., Gmaian, I., \& Al-Shudaifat, S. (2013). Sex education as viewed by Islam education. European Journal of Scientific Research, 95(1), 5-16. https://eis.hu.edu.jo/deanshipfiles/pub106956271.pdf

Astle, S., McAllister, P., Emanuels, S., Rogers, J., Toews, M., \& Yazedjian, A. (2021). College students' suggestions for improving sex education in schools beyond 'blah blah blah condoms and STDs'. Sex Education, 21(1), 91-105. https://doi.org/10.1080/14681811.2020.1749044

Barratt, B. B. (2008). Evaluating brief group interventions in sexuality education and enhancement: Do workshops really work? American Journal of Sexuality Education, 3(4), 323-343. https://doi.org/10.1080/15546120802371992

Bouclaous, C.H., Alrazim, A., Chababi, J., Jamaleddine, W., Nassar, E., Maalouf, A., Aridy, S.D., Naccache, M., Abboud, D.M., Assi, M., \& Slika, M. (2021). Association between sources of sexuality education, sexual beliefs and behaviours in Lebanese young adults: A university-based cross-sectional study. Sex Education, 21(1), 1-12. https://doi.org/10.1080/14681811.2020.1722624

Bozdemir, N., \& Özcan, S. (2011). Cinselliğe ve cinsel sağlığa genel bakış. Turkish Journal of Family Medicine and Primary Care, 5(4), 37-46. https://dergipark.org.tr/tr/pub/tjfmpc/issue/45318/567767

Brayboy, L. M., Sepolen, A., Mezoian, T., Schultz, L., Landgren-Mills, B. S., Spencer, N., Wheeler, C., \& Clark, M. A. (2017). Girl TALK: A smartphone application to teach sexual health education to adolescent girls. Journal of Pediatric and Adolescent Gynecology, 30(1), 23-28. https://doi.org/10.1016/j.jpag.2016.06.011

Buston, K., Wight, D., \& Hart, G. (2002). Inside the sex education classroom: The importance of context in engaging pupils. Culture, Health \& Sexuality, 4(3), 317-335. https://doi.org/10.1080/13691050110113332

Byers, E. S., Sears, H. A., Voyer, S. D., Thurlow, J. L., Cohen, J. N., \& Weaver, A. D. (2003). An adolescent perspective on sexual health education at school and at home: I. high school students. Canadian Journal of Human Sexuality, 12(1), 1-17. http://eds.a.ebscohost.com/eds/pdfviewer/pdfviewer?vid=0\&sid=ee7a124f8929-478d-a82b-cc9e1667dc79\%40sessionmgr4006

Cinsel Eğitim Tedavi ve Araştırma Derneği ( CETAD). (2006). Cinsel sağlık ve üreme sağlığı alanında ulusal ve yerel medya yoluyla savunuculuk projesi, Bilgilendirme Dosyası 1: Cinsel yaşam ve sorunları. Ed: Şahin D, Şimşek F, Seyisoğlu H. https://cetad.org.tr/CetadData/Books/21/pdf-dosyasini-indirmek-icin-tiklayiniz.pdf

Çalışandemir, F., Bencik, S., \& Artan, İ. (2010). Çocukların cinsel eğitimi: geçmişten günümüze bir bakış. Ĕgitim ve Bilim, 33(150), 15-27. http://egitimvebilim.ted.org.tr/index.php/EB/article/view/627/97

Çuhadaroğlu, A. (2017). The effects of sex education on psychological counselling students in Turkey. Sex Education, 17(2), 209-219. https://doi.org/10.1080/14681811.2016.1164132

Grose, R. G., Grabe, S., \& Kohfeldt, D. (2014). Sexual education, gender ideology, and youth sexual empowerment. Journal of Sex Research, 51(7), 742-753. https://doi.org/10.1080/00224499.2013.809511

Haruna, H., Hu, X., Chu, S., Mellecker, R. R., Gabriel, G., \& Ndekao, P. S. (2018). Improving sexual health education programs for adolescent students through game-based learning and gamification. International Journal of Environmental Research and Public Health, 15(9), 2027, 1-26. https://doi.org/10.3390/ijerph15092027

International Children's Center. (n.d.). Adolesan ve üreme sağliği ve haklarl. http://www.icc.org.tr/icerik.php?id=12\&kid=3. 
Kohler, P. K., Manhart, L. E., \& Lafferty, W. E. (2008). Abstinence-only and comprehensive sex education and the initiation of sexual activity and teen pregnancy. The Journal of Adolescent Health, 42(4), 344-351. https://doi.org/10.1016/j.jadohealth.2007.08.026

Leung, H., Shek, D. T., Leung, E., \& Shek, E. Y. (2019). Development of contextually-relevant sexuality education: Lessons from a comprehensive review of adolescent sexuality education across cultures. International Journal of Environmental Research and Public Health, 16(4), 621, 1-24. https://doi.org/10.3390/ijerph16040621

Lin, Y. L., \& Lin, Y. C. (2018). Effectiveness of the sexual attitude restructuring curriculum amongst Taiwanese graduate students. Sex Education, 18(2), 140-156. https://doi.org/10.1080/14681811.2017.1410698

Maryland, M. A., \& Gonzalez, R. I. (2012). Patient advocacy in the community and legislative arena. Online Journal of Issues in Nursing, 17(1), 2.

https://ojin.nursingworld.org/MainMenuCategories/ANAMarketplace/ANAPeriodicals/OJIN/TableofContent s/Vol-17-2012/No1-Jan-2012/Advocacy-in-Community-and-Legislative-Arena.html

Nadeem, A., Cheema, M. K., \& Zameer, S. (2021). Perceptions of Muslim parents and teachers towards sex education in Pakistan. Sex Education, 21(1), 106-118. https://doi.org/10.1080/14681811.2020.1753032

Narushima, M., Wong, J. P. H., Li, A. T. W., Bhagat, D., Bisignano, A., Fung, K. P. L., \& Poon, M. K. L. (2020). Youth perspectives on sexual health education: Voices from the YEP study in Toronto. Canadian Journal of Human Sexuality, 291(1), 32-44. https://doi.org/10.3138/cjhs.2019-0049

Oosterhoff, P., Müller, C., \& Shephard, K. (2017). Introduction: Sex education in the digital era. IDS Bulletin, 48(1), 1-6. https://doi.org/10.19088/1968-2017.102

Robinson, K. H., Smith, E., \& Davies, C. (2017). Responsibilities, tensions and ways forward: Parents' perspectives on children's sexuality education. Sex Education, 17(3), 333-347. https://doi.org/10.1080/14681811.2017.1301904

Sağlık Bakanlığı Ana Çocuk Sağlığı ve Aile Planlaması Genel Müdürlüğü, Cinsel Sağlık ve Üreme Sağlığ1 Ulusal Stratejiler ve Eylem Planı 2005-2015, Ankara, 2005.

https://sbu.saglik.gov.tr/Ekutuphane/kitaplar/a\%C3\%A7sap9.pdf

Seiler-Ramadas, R., Mosor, E., Omara, M., Grabovac, I., Schindler, K., Niederkrotenthaler, T., \& Dorner, T. E. (2021). 'We're going around the subject'improving sex education and adolescents' awareness of sexually transmitted infections: A qualitative study. Sex Education, 21(1), 119-132. https://doi.org/10.1080/14681811.2019.1668761

Shams, M., Parhizkar, S., Mousavizadeh, A., \& Majdpour, M. (2017). Mothers' views about sexual health education for their adolescent daughters: A qualitative study. Reproductive Health, 14(1), 1-6. https://doi.org/10.1186/s12978-017-0291-8

Sommart, J., \& Sota, C. (2013). The effectiveness of a school-based sexual health education program for junior high school students in Khon Kaen, Thailand. Procedia-Social and Behavioral Sciences, 91, 208-214. https://doi.org/10.1016/j.sbspro.2013.08.419

Sprecher, S., Harris, G., \& Meyers, A. (2008). Perceptions of sources of sex education and targets of sex communication: Sociodemographic and cohort effects. Journal of Sex Research,45(1), 17-26. https://doi.org/10.1080/00224490701629522

Stephenson, J. M., Strange, V., Forrest, S., Oakley, A., Copas, A., Allen, E., Babiker, A., Black, S., Ali, M., Monteiro, H., Johnson, A. M., \& RIPPLE study team (2004). Pupil-led sex education in England (RIPPLE study): Cluster-randomised intervention trial. Lancet, 364(9431), 338-346. https://doi.org/10.1016/S01406736(04)16722-6

UNFPA (2018), Implementation of sexuality education in middle schools in China, https://china.unfpa.org/en/publications/cse/20181105

Wanje, G., Masese, L., Avuvika, E., Baghazal, A., Omoni, G., \& Scott McClelland, R. (2017). Parents' and teachers' views on sexual health education and screening for sexually transmitted infections among in-school adolescent girls in Kenya: A qualitative study. Reproductive Health, 14(1), 1-11. https://doi.org/10.1186/s12978-017-0360-z

Wong, T., Pharr, J. R., Bungum, T., Coughenour, C., \& Lough, N. L. (2019). Effects of peer sexual health education on college campuses: A systematic review. Health Promotion Practice, 20(5), 652-666. https://doi.org/10.1177/1524839918794632

World Health Organization. (1975). Education and treatment in human sexuality: The training of health professionals, report of a WHO meeting [ held in Geneva from 6 to 12 February 1974]. World Health Organization. https://apps.who.int/iris/handle/10665/38247 
World Health Organization. (2006). Defining sexual health: Report of a technical consultation on sexual health, 28-31 January 2002, Geneva. World Health Organization. https://www.who.int/reproductivehealth/publications/sexual_health/defining_sh/en/

World Health Organization. (2010). WHO's strategic vision in sexual and reproductive health and rights: Business plan 2010-2015 (No. WHO/RHR/10.10). World Health Organization. https://www.who.int/reproductivehealth/publications/reports/rhr_10_10/en/

Zeren, F., \& Gürsoy, E. (2018). Neden cinsel sağlık eğitimi? Düzce Üniversitesi Sağllk Bilimleri Enstitüsü Dergisi, 8(1), 29-33. https://dergipark.org.tr/tr/download/article-file/451039 